\title{
PHYSICAL AND CHEMICAL STUDIES OF THE ORGANIC MATTER OF UPPER DEVONIAN BROWN COALS
}

\author{
L. S. Kocheva1, A.P. Karmanov'2, S.M. Snigirevsky3, 4 \\ ${ }^{1}$ Institute of Geology, Komi SC UB RAS, Syktyvkar; lskocheva@geo.komisc.ru \\ ${ }^{2}$ Institute of Biology, Komi SC UB RAS, Syktyvkar; apk0948@yandex.ru \\ ${ }^{3}$ St. Petersburg State University, St. Petersburg; s.snigirevsky@spbu.ru \\ ${ }^{4}$ Komarov Botanical Institute, St. Petersburg; s.snig@mail.ru
}

\begin{abstract}
We presented results of comparative physical and chemical studies of the organic matter of Devonian brown coals and rocks with carbonized plant residues from Northern Timan. We used IR Fourier spectroscopy of diffuse reflection, ESR spectroscopy, quantitative chemical analysis, pyrolytic gas chromatography-mass spectrometry.
\end{abstract}

Keywords: brown coal, carbonized plant residues, Devonian, Northern Timan, physical-chemical research methods.

\section{ФИЗИКО-ХИМИЧЕСКОЕ ИССЛЕДОВАНИЕ ОРГАНИЧЕСКОГО ВЕЩЕСТВА ВЕРХНЕДЕВОНСКИХ БУРЫХ УГЛЕЙ}

\author{
Л. С. Кочева 1 , А. П. Карманов², С. М. Снигиревский ${ }^{3,4}$ \\ ${ }^{1}$ Институт геологии Коми НЦ УрО РАН, Сыктывкар \\ ${ }^{2}$ Институт биологии Коми НЦ УрО РАН, Сыктывкар \\ ${ }^{3}$ Санкт-Петербургский государственный университет, Санкт-Петербург \\ ${ }^{4}$ Ботанический институт им. В. Л. Комарова РАН, Санкт-Петербург
}

Приводятся результаты сравнительных физико-химических исследований органического вещества девонских бурых углей и пород с углефицированными растительными остатками Северного Тимана. Использованы методы: ИК-Фурье-спектроскопия диффузного отражения, ЭПР-спектроскопия, количественный химический анализ, пиролитическая газовая хромато-масс-спектрометрия.

Ключевые слова: бурый уголь, углефицированные растительные остатки, девон, Северный Тиман, физико-химические методы исследования.

Devonian brown coals of Northern Timan are traditionally considered unsuitable for development and industrial use because of their low quality, low power and low calorific value. However, recent finds of remains of primitive quadruped animals, including Devonian tetrapods $[1,6]$, in Famennian deposits on the Volonga River attracted a new scientific interest in Devonian coal deposits.

A distinctive feature of Devonian brown coals of Northern Timan is their low maturity and absence of significant catagenetic transformations of organic matter. Thus, the brown coals of Northern Timan present a source of valuable information about the nature and properties of various components of coalforming plants. Researchers are primarily interested in lignin, which is one of the most chemically stable biopolymers of plant origin.

In $[4,5]$ it was noted the plant polymer of aromatic nature - lignin - played an important role in coal, peat and soil formation. The basis of the chemical structure of lignins is a phenylpropane unit. By composition, all known modern lignins are subdivided into coniferous or guaiacyl (G-type), deciduous or guaiacyl-syringyl (GS-type) and grassy or guaiacyl-syringyl-p-coumaric (GSH-type) (Fig. 1). Until now, the first, the least evolutionarily advanced, G-type lignins (coniferous lignins) were considered [3].

Lignin is one of the most chemically resistant compounds of plant origin. It has been established that during the thermal treatment of plant material the natural lignin, as a result of destructive metamorphic transformations, can be basis for various compounds that preserve the aromatic nature. Analysis of destruction products allows to establish features of the chemical structure of the original substance.

In particular, vanillin, mellitic, and benzene pentacarboxylic acids were found in organic matter from the mineralized residues of Lepidodendropsis stems, at that a lower number of methoxy groups was noted compared to modern conifers [4]. In younger coals the oligolignols of aromatic nature and methylated phenylpropane compounds, related to $\mathrm{G}, \mathrm{S}$, and H-type structures were founded [7, 13].

The aim of the work: comparative physical and chemical characteristic of the organic matter of the brown coals of Northern Timan.

\section{Objects and research methods}

The objects of study (UD-1 - UD-9) were Upper Devonian brown coals and rocks with carbonized plant residues from 
Famennian Pokayama Formation on the Volonga River (Northern Timan, Russia). Legend and descriptions of the studied samples are given in Table 1.
An exception is the concentration of free organic carbon radicals $\mathrm{n}_{\text {org }}$ (Table 2). Compared to modern lignins and UD11 (Jurassic), Devonian coals samples have a very high con-

Table 1. Characteristic of the brown coals and carbonized plant residues from Northern Timan

Таблица 1. Характеристика девонских бурых углей и углефицированных растительных остатков Северного Тимана

\begin{tabular}{|c|c|l|}
\hline Sample & Sample No. & \multicolumn{1}{c|}{ Description } \\
\hline UD-1 & $16-12 / 1$ & Layer of coal with spherical pyrite nodules in the roof of a pack of clay \\
\hline UD-2 & $3-$ VI-2016 & Thin laycr of paper-coal at the basc of cross-stratificd sandstones \\
\hline UD-3 & $4-$ VIII-I-2016 & Carbonized stem or root of Callixylon sp. plant \\
\hline UD-4 & $4-X I-2 a$ & Layer of coal in a siltstone lens with remains of Phyllolepis, representing an incision of bayou lake \\
\hline UD-5 & $3-$ II-2016 & Layer of coal from a paleoriver bed incision \\
\hline UD-6 & $6-25 a-2016$ & Carbonized layer in a pack of siltstones \\
\hline UD-7 & $7-\mathrm{I}-2016$ & Layer of coal in a pack of siltstones \\
\hline UD-8 & $10-\mathrm{I}-16-2016$ & Layer of coal in argillites \\
UD-9 & $11-8-$-np. Hu3. & Layer of coal in a pack of sandstones, siltstones and clays \\
\hline
\end{tabular}

We used carbonized fragments of Callixylon tree trunks, from the Tsilma River, Middle Timan, Russia, outcrop № 44, Devonian, (sample UD-10) and ancient redeposited carbonized plant residues from modern alluvial river bed sediments of the Sysola River, Griva, Komi Republic, Russia, Jurassic (sample UD-11) [9]. We also used lignin preparations by Pepper's dioxane method [12] from modern plants: oats (DLO), larch (DLL), and poplar (DLP).

IR Fourier spectra of diffuse reflection were recorded by IR Prestige-21 Shimadzu spectrometer, Japan. KBr tablets (200 mg) were used to register the spectra $(1 \mathrm{mg})$. The ESR spectra were obtained by SE/X-2547 RadioPAN radiospectrometer. As a standard for the concentration of paramagnetic centers, a certified DFPG 910-06/07 sample with the number of spins $1.96 \cdot 10^{17}$ was used. Quantitative chemical analysis was performed by gas chromatography (Elemental Analyzer EA 1110 (CHNS-O), Italy, CE Instruments). The samples were pyrolyzed with GCMS-QP2010 Plus gas chromatography-mass spectrometer with EGA/PY3030D pyrolyzer (Frontier lab, Japan) under gradual heating from 100 to $900{ }^{\circ} \mathrm{C}$ at a rate of $50{ }^{\circ} \mathrm{C} / \mathrm{min}$.

\section{Results and discussion}

IR Fourier spectra of diffuse reflection of the studied samples (Fig. 2), in general, are a superposition of bands of aromatic fragments, a mineral component, aliphatic $\mathrm{CH}$ groups and water. On all spectrums there are bands at 1600, 1632, 1612, 1570,1509 and $870 \mathrm{~cm}^{-1}$. It should be noted the range of wave
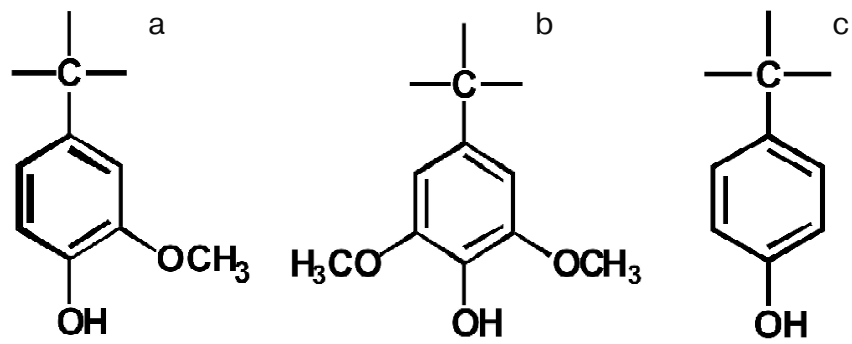

Fig. 1. Lignin structural units: a - guaiacyl (G); b - syringyl (S);

$$
\mathrm{c}-p \text {-coumaric }(\mathrm{H})
$$

Рис. 1. Структурные единицы лигнина: а - гваяцильная (G); б - сирингильная (S); в - n-кумаровая $(\mathrm{H})$

numbers from 800 to $900 \mathrm{~cm}^{-1}$, where $\mathrm{CH}$ bonds of aromatic rings are absorbed, as well as to the region of skeletal vibrations of the aromatic ring $\sim 1600 \mathrm{~cm}^{-1}$.

The comparative analysis of the ESR spectra (Fig. 3) shows that by the main characteristics, the studied samples and comparison samples, including modern lignins, are close to each other (Table 2). Thus, the most intense signal in all ESR spectra is a narrow line with an electroscopic g-factor 2.003-2.004, which corresponds to a phenoxyl radical, existing in several mesomer forms. The shape of the line is Lorentzian with a slight asymmetry characteristic of aromatic structures. The line width at the extreme points $\left(\Delta \mathrm{B}_{\mathrm{pp}}\right)$ is $0.6-0.8 \mathrm{mT}$.

Table 2. Parameters of ESR-spectra of the studied samples

Таблица 2. Параметры ЭПР-спектров исследуемых образцов

\begin{tabular}{|c|c|c|c|c|c|}
\hline Sample & Content $\mathrm{C}+\mathrm{N}+\mathrm{H}, \%$ & $\mathrm{~g}$-factor & $\Delta \mathrm{B}_{\mathrm{pp}}, \mathrm{mT}$ & Line shape & $\mathrm{n}_{\mathrm{opr}}, 10^{17} \mathrm{spin} / \mathrm{g}$ \\
\hline UD-1 & 35.37 & $2 / 0036$ & 0.74 & $\sim \mathrm{L}$, ass & 150.0 \\
\hline UD-2 & 56.50 & 2.0036 & 0.75 & $-\ll-$ & 400.0 \\
UD-3 & 27.07 & 2.0036 & 0.70 & $-\ll-$ & 190.0 \\
\hline UD-4 & 28.06 & 2.0036 & 0.77 & $-\ll-$ & 100.0 \\
\hline UD-5 & 42.70 & 2.0036 & 0.71 & $-\ll-$ & 150.0 \\
\hline UD-6 & 22.64 & 2.0036 & 0.72 & $-\ll-$ & 190.0 \\
\hline UD-7 & 43.64 & 2.0036 & 0.78 & $-\ll-$ & 870.0 \\
\hline UD-8 & 70.78 & 2.0035 & 0.74 & $-\ll-$ & 1040.0 \\
\hline UD-9 & 17.88 & 2.0035 & 0.74 & $-\ll-$ & 2440.0 \\
\hline UD-10 & 79.8 & 2.0031 & 0.64 & $-\ll-$ & 350.0 \\
\hline UD-11 & 60.3 & 2.0039 & 0.77 & $-\ll-$ & 13.0 \\
\hline DLO & 65.1 & 2.0044 & 0.78 & $-\ll-$ & 2.2 \\
\hline DLL & - & 2.0041 & 0.72 & $-\ll-$ & 0.04 \\
\hline DLP & - & 2.0038 & 0.62 & $-\ll-$ & 0.04 \\
\hline
\end{tabular}




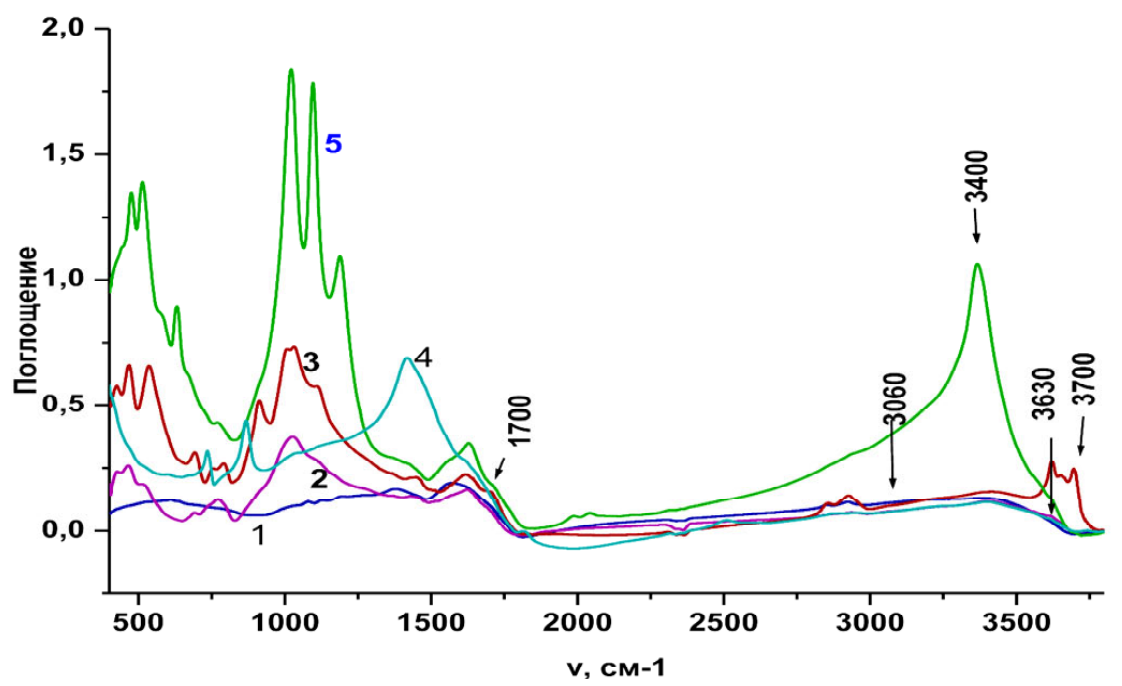

Fig. 2. IR Fourier spectra of diffuse reflection of Upper Devonian brown coals samples: 1 - UD-3; 2 - UD-7; 3 - UD-5; 4 - UD-9; 5 - UD-4

Рис. 2. ИК-Фурье-спектры диффузного отражения образцов верхнедевонских бурых углей: 1 - УД-3; 2 - УД-7; 3 - УД-5; 4 - УД-9; 5 - УД-4

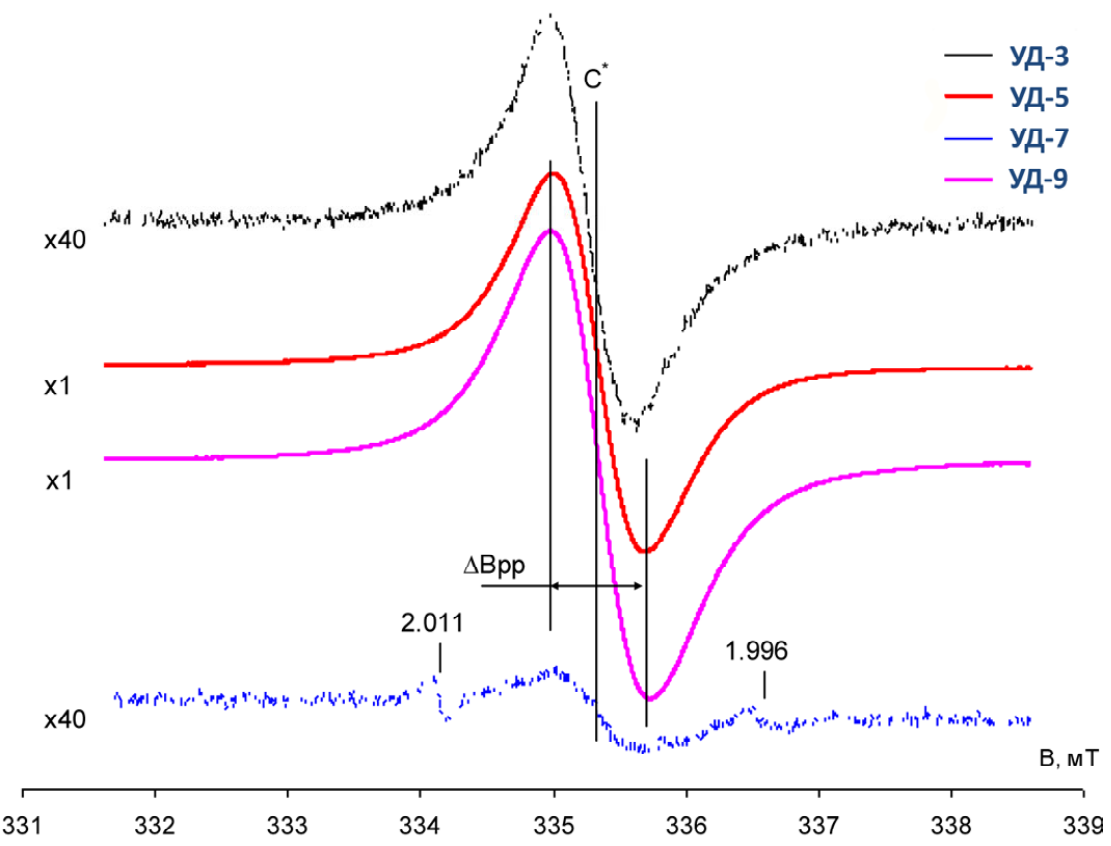

Fig. 3. Line of carbon radicals in ESR spectra of samples of Upper Devonian brown coals and carbonized plant residues

Рис. 3. Линия углеродных радикалов в ЭПРспектрах образцов верхнедевонских бурых углей и углефицированных растительных остатков

centration of paramagnetic centers, reaching a maximum value for carbonaceous substances in sample UD- $9-10^{20} \mathrm{spin} / \mathrm{g}$. This is certainly related to peculiarities of the chemical structure of plant origin organic matter.

Phenols in the products of pyrolysis of the Upper Devonic organic matter (kerogen) of the Pechora Basin Sargaev sediments were first described in the work [2]. The analysis of results of a low molecular destruction products of the studied plant origin samples (Fig. 4) by pyrolytic gas chromatography-mass spectrometry shows that the main pyrolysis compounds are aromatic, including phenolic, compounds: benzene, toluene, $m$ xylene, phenol, $o$-cresol, $n$-cresol.

The quantitative analysis of phenolic products of pyrolysis by the peaks area of the gas chromatogram allowed to calculate the ratio of the main structural units $\mathrm{H}, \mathrm{G}$ и $\mathrm{S}$. According to the obtained data, the units $\mathrm{H}$ dominate in samples of Upper Devonian brown coals and rocks with carbonized plant residues. UD10 sample (Middle Timan, Devonian) shows a similar result. Jurassic UD-11 sample presents a different ratio of structural units. The number of $\mathrm{G}$ units is $14.8 \%$. On the one hand, these results are consistent with the conclusion of the works $[8,10,11]$, according to which the general order of lignins resistance is $p$-cou- maryl $(H)$. guaiacyl $(G)$. syringyl $(S)$. On the other hand, the obtained experimental data raise new questions about evolutionary transformations of lignin, since lignin performed the function of plant adaptation to changing environmental conditions.

Table 3. Ratio of structural units in the studied samples according to pyrolytic gas chromatography-mass spectrometry

Таблица 3. Соотношение структурных единиц в исследуемых образцах по данным пиролитической газовой хромато-масс-спектрометрии

\begin{tabular}{|c|c|}
\hline Sample & Ratio H:G:S, \% \\
\hline UD-1 & $97.9: 2.0: 0.1$ \\
\hline UD-2 & $99.4: 0.4: 0.2$ \\
\hline UD-3 & $99.5: 0.3: 0.2$ \\
\hline UD-4 & $97.1: 1.8: 1.1$ \\
\hline UD-5 & $99.8: 0.1: 0.1$ \\
\hline UD-6 & $98.4: 0.7: 0.9$ \\
\hline UD-7 & $99.9: 0.1: 0$ \\
\hline UD-8 & $99.9: 0.1: 0$ \\
\hline UD-9 & $99.7: 0.2: 0.1$ \\
\hline UD-10 & $99.5: 0.5: 0$ \\
\hline UD-11 & $85.2: 14.8: 0$ \\
\hline
\end{tabular}




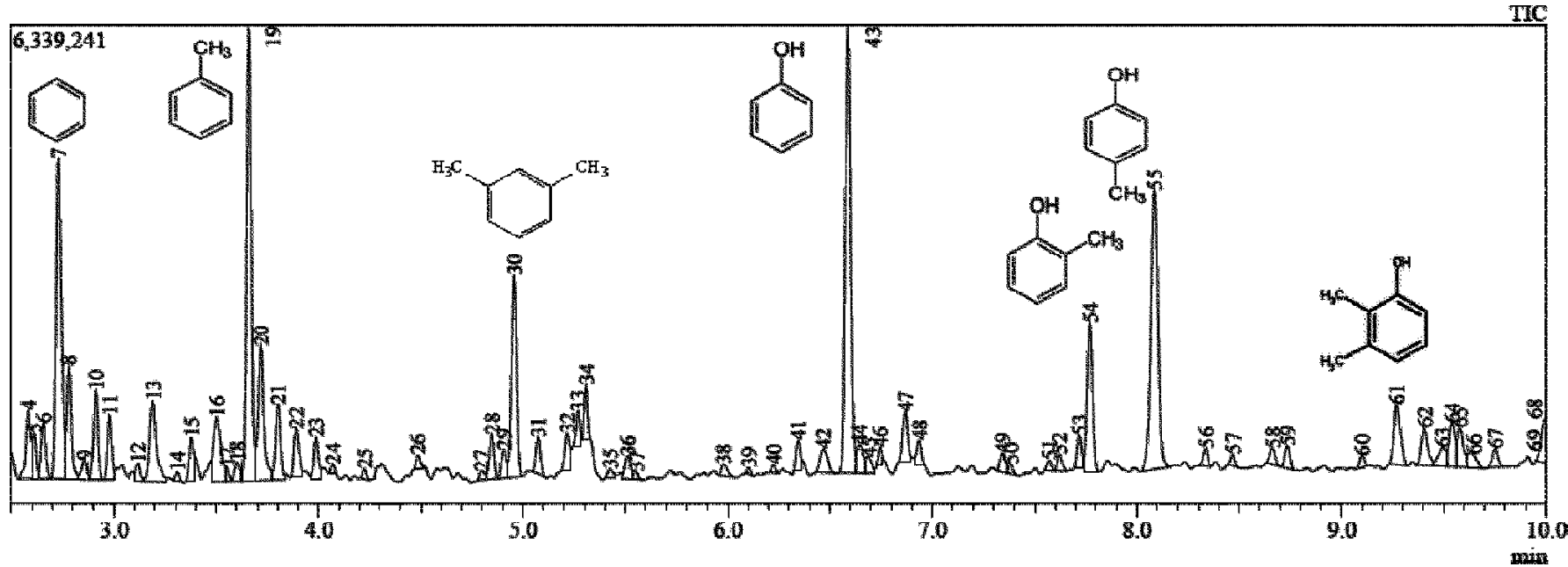

Fig. 4. Gas chromatogram of UD-5 (b) sample in the region of major low molecular pyrolysis components

Рис. 4. Газовая хроматограмма образца УД-5 (б) в области мажорных низкомолекулярных компонетов пиролиза

\section{Conclusions}

1) On the basis of the complex of physical-chemical methods, we studied the organic matter of Devonian brown coals and rocks with carbonized plant residues from the section of Famennian Pokayama Formation along the Volonga River (Northern Timan).

2) Studied samples are characterized by a very high concentration of paramagnetic centers, reaching a value close to the maximum value $\mathrm{n}_{\text {org }}$ for carbonaceous substances.

3) According to quantitative analysis of data on the products of thermal destruction we showed that $p$-coumaryl $(\mathrm{H})$ units dominate in investigated samples.

The studies were carried out as part of the State Task (SRW) of the Institute of Geology, Komi SC UB RAS; work supported by SPbSU (project № 41129192). The authors are grateful to P. A. Beznosov (Syktyvkar), V. P. Lyutoev (Syktyvkar), S. A. Pokryshkin (Arkhangelsk) and O.Yu. Derkacheva (St. Petersburg) for assistance in the researches.

\section{References}

1. Beznosov P. A., Snigirevsky S. M., Naugolnykh S. V., Lukshevich E. V. Verhnedevonskij kompleks otlozhenij del'tovoj ravniny na Severnom Timane (Upper Devonian complex of deltaic sediments in Northern Timan). Vestnik IG Komi SC UB RAS, 2018, No. 1 (277), pp. 25-44.

2. Bushnev D. A. Osobennosti-sostava biomarkerov bitumoida I produktov piroliza kerogena otlozhenij verhnego devona Pechorskogo bassejna (Features of the composition of biomarkers of bitumen and kerogen products pyrolysis of the Upper Devon Pechora basin deposits). Neftechimiya. 2002, V. 42, No. 5, pp. 325-339.

3. Ligniny (struktura, svojstva i reakcii) (Lignins (structure, features and reactions). Ed. K. Sarkanen, K. Lyudvig. Moscow: Lesnaya promyshlennost, 1975, 632 p.
4. Manskaya S. M., Kodina L. A. Geohimiya lignina (Lignin geochemistry). Moscow: Nauka, 1975, 232 p.

5. Peresypkin V. I., Romankevich E. A. Biogeohimiya lignina (Lignin biogeochemistry). Moscow: Geos, 2010, 340 p.

6. Ahlberg P. E., Beznosov P. En extremely primitive miniature tetrapod from the Late Devonian (Early Famennian) of North Timan, Russia. Abstracts of the 66th Symposium of Vertebrate Palaeontology and Comparative Anatomy and the 27th meeting of the Symposium of Palaeontological Preparation and Conservation. Manchester, 2018, pp. 29.

7. Dutta S., Bhattacharya S., Mallick M., Shukla A. C., Mann U. Preserved lignin structures in Early Eocene Surat lignites, Cambay Basin, Western India. J. Geolog. Soc. India. 2012, V. 79, No. 4, pp. $345-352$.

8. Hedges J. I., Cowie G. L., Ertel J. R., Barbour R. J., Hatcher P. G. Degradation of carbohydrates and lignins in buried woods. Geochim. Cosmochim. Acta, 1985, V. 49, pp. 701-711.

9. Kocheva L. S., Karmanov A. P., Lutoev V. P., Shumilov I. Kh., Glukhov Yu. V., Pokryshkin S. A. Structural and Chemical Features of Organic Matter in Carbonized Wood of the Devonian and Jurassic Periods. Doklady Earth Sciences, 2019, V. 486, Part 2, pp. 634-637.

10. Logan K. J., Thomas B. A. Distribution of lignin derivatives in plants. The New Phytologist, 1985, V. 99, pp. 571-585.

11. Orem W. H., Neuzil S. G., Lerch H. E., Cecil C. B. Experimental early-stage coalification of a peat sample and a peatified wood sample from Indonesia. Organic Geochemistry, 1996, V. 24, pp. 111-125.

12. Pepper J. M., Baylis P. E., Adler E. The isolation and properties of lignin obtained by the acidolysis of spruce and aspen woods in dioxane-water. Canad. J. Chem, 1959, V. 37, No. 8, pp. $1241-1245$.

13. Saikia B. K., Boruah R. K., Gogoi P. K. FT-IR and XRD analysis of coal from Makum coalfield of Assam. J. Earth Syst. Sci, 2007, V. 116, No. 6, pp. 575-579. 